\title{
EVEN THE GODS DIE . . . \\ THE STATE FUNERAL AND NATIONAL MOURNING FOR THE ALBANIAN COMMUNIST DICTATOR ENVER HOXHA
}

\section{BLEDAR KONDI}

This paper focuses on the death, state funeral, and national mourning for the Albanian communist dictator Enver Hoxha (1908-1985). This exploration of the emotional experiences and cultural strategies of coping with the death of a deathless leader aims to shed light on the performative roles of the ruling party, the workers, and the class enemies, as well as on the methods of ruling in a dictatorial system.

Keywords: Enver Hoxha, death, mass mourning, state funeral
V̌̀lanku so obravnavani smrt. državni pogreb in nacionalno žalovanje za albanskim komunističnim diktatorjem Enverjem Hoxho (1908-1985). Raziskava emocionalnih izkušenj in kulturnih strategij za spoporijem s smrtjo neumrljivega vodje želi osvetliti performativno vlogo vladajoče stranke, delavcev in razrednih sovražnikov ter tudi metode vladanja $v$ diktatorskem sistemu.

Ključne besede: Enver Hoxha, smrt, množično žalovanje, državni pogreb

\section{INTRODUCTION}

"The dictator died, but the dictatorship continued."

—Former political prisoner
"The star fell, but its light remained."

-WWII veteran

Enver Hoxha is one of the longest-serving communist leaders in the world. He ruled Albania for more than 40 years, following his "special Albanian path." After coming into power in 1944, the "Balkan ex-Muslim Stalinist" (Halliday 1986: 6) "killed god"1 and became a replacement deity for the youthful generation, transformed Albania from a backward post-Ottoman province into a modern industrial country, installed a violent isolationism, and led a life hollowed by paranoia (Lendvai 1985: 64-65; Fischer 2007: 249-266; Mëhilli 2011: 7-13). Hoxha's first (natural) death in 1985 and second (political) death in 1991 generated a full circle of events, from the immortalization to the damnation of an absolute monarch and from anti-communist iconoclasm to bittersweet nostalgia for the dictatorship. The apparatus of sonic and visual (re)presentation of the leader's loss was construed to produce effects about the entire history of Albanian communism, and especially the life and deeds of a man "born of a mother, reborn of the Party" (i.e., Enver Hoxha). The weeklong funeral commemorations, the public work of mourning, commemorative rites, and national folk festivals, and his Pharaonic glorification in a pyramidal museum were

1 After systematic persecution of the clergy, ca. 740 mosques, 530 tekkes and turbes, 608 Orthodox churches, and 157 Catholic ones were closed within a few months in atheist Albania in 1967. They were partly maintained as "cultural monuments," partly transformed into cinemas, storage depots, and sports venues, and some were destroyed (Bartl 1995: 255). 
required to demonstrate how one's physical mortality in individuo is transcended by political immortality in genere. Though obsequies would mark a smooth transfer of power, the irreplaceable loss of the "sultan rouge" contained the seeds of the end of the communist regime. The female vocalization of painful shock and grief through the public rituals of "crying with howls" (e qarë me ulërimë) and "crying with words" (e qarë me ligje) ${ }^{2}$ aimed to tell of the unspeakable, release the unbearable, and deny the unimaginable: the death of the deathless leader.

State funerals and public mourning for great communist leaders constitute a great show of panic, sorrow, and devotion that was repeatedly restaged in the past century of catastrophes. Paradoxically, the more information we have about the criminal misadventures of communism against populations and national cultures, the less we seem to understand the mass mourning for a past dictator, the inherently human "thirst for obedience," and the apparent "longing for self-sacrifice" (Freud 2001: 91). Hannah Arendt has clarified the tremendous difference in the attitudes of German workers and Russian peasants towards their rulers in the first half of the twentieth century: "the former looked upon a not too beloved monarch as the symbol of national unity, and the latter considered the head of their government to be the true representative of God on earth" (Arendt 1962: 237). It is no wonder that the natural death of a leader regarded as a repository of power and authority based on an unchanging eternal order signifies an intolerable scandal and causes a true panic in a headless society. ${ }^{3}$

The shocking death of Lenin made Russian people burst into "unmistakable grief," "unanimous sobs," "wails," and "crying like children" in a "hysterical frenzy" (Tumarkin 1983: 134-140). There was unprecedented mass hysteria upon Stalin's death, when a mourning crowd moving chaotically towards Moscow was crushed and trampled to death in the train station (Koenen 1992: 260). Even the people whom Stalin had put in prison and labor camps were "reduced to tears" at the news of his loss (Schoeberlein 2003: 218). Kim Il-sung and Kim Jong-il in North Korea were mourned by brainwashed masses in a paroxysmaltheatrical style, but "poor mourning" for the great leader was punished immediately by the higher authorities (Min 2012). The death of a beloved politician like Zhou Enlai in 1976

2 The Lab area in southern Albania is well-known for the emotional power of its funeral performances and the poetic virtuosity of its many crying-women, who have strongly influenced the mournful polyphonic songs of the men and their instrumental repertoire. According to the Lab custom, a woman "cries with tears" (qan me lotë), "cries with voice" (qan me zë), and "cries with words" (qan me ligje), which means she sobs, complains aloud, and laments for the dead through the melodic-poetic formulas of the village. The technical term e qarë me ulurimë (lit. "crying with a howl") means "to announce death with howls" and it has been reserved for mutual exchanges of vocal signals between the bereaved kinswomen on the way to the house of the deceased (Kondi 2012: 127-190, 313-319).

3 Concerning the so-called "funeral anarchies" or "ritualized tumults" caused by the deaths of emperors, kings, or political leaders in a historical and transcultural perspective see also Di Nola 2003: 63-69, 538-555. For comprehensive documentation of the state funerals and political cults of twentieth-century dictators, see Koenen 1992; Verdery 1997; Rader 2003: 222-249; Borneman 2004; Großbolting and Schmidt 2011. 
shook 900 million people in the People's Republic of China, but the "leftists" prohibited every spontaneous demonstration of grief beyond the official frame of reference. The loss of Mao Zedong some months later urged the common people to again show to the world their "ability to mourn." Despite the "shocking scenes" in front of the cameras, Western journalists observed that national mourning for Mao was a well-orchestrated ritual, in which nothing was left to chance (Koenen 1992: 436-39). Mass grieving for charismatic controversial figures uncovers a special type of "normative disorganization" based on the ideological ethos of situation. Release creates the crowd, but despite the contagious power of genuine feelings, the imposed "uniformity does not produce strong emotions" (Durkheim 2001: 74). The relationship between individual emotional states and social conventional attitudes in dictatorial systems, namely the impersonality of mourning, can be approached from the sociological theory of mourning in pre-industrial societies: (1) "mourning is not the spontaneous expression of individual emotions"; (2) "there is no connection between the feelings experienced and the gestures performed by the actors of the rite"; (3) "[people] lament not simply because they are sad, but because they are compelled to lament" (op. cit.: 2001: 295). The death of a deified dictator breaks apart the ideologically frozen forms of collective consciousness and the synchronized rhythm of communist life; it sheds light on the unpredictable past ${ }^{4}$ of the regime and contributes to an essential understanding of "dictatorship as experience."

\section{A MISSING SOURCE AND DESTROYED DOCUMENTARY EVIDENCE}

The state funeral and public mourning for the "Beloved Great Leader" 5 constitute a unique cultural event in Albanian history and a significant representation of a closed society. The funeral commemorations for the head of the state, lasting from April 11th to 18th, 1985, were the first to be broadcast live on Albanian television. After the collapse of the dictatorship in 1991, almost all audiovisual recordings of the funeral commemorations-no less than seventy-two hours' worth-disappeared without a trace from the Albanian RadioTelevision (RTSH) archive. ${ }^{6}$ Some live footage of the funeral ceremony in the capital city of Tirana was "artistically elaborated" by Kinostudio (a film production company), and

4 "The past cannot be predicted, because even it obeys the changes of the party line" (Alexander Vatlin, quoted in Großbölting and Schmidt 2011: 11).

5 During the funeral commemorations, the official media glorified Enver Hoxha as a "beloved great leader," a "precious son of the people," a "glorious commander," a "great teacher," and so on.

6 It is rumored that many recordings and personal diaries of Enver Hoxha might have been given to a favorite journalist of the commercial broadcaster Klan. One of the fifty camera operators that shot Hoxha's funeral ceremony told me that the film cassettes varied from three to twelve minutes and the archival collection comprised more than 400 cassettes. He further added that in 1992 "anticommunist" directors threw away many historical tapes and the peasants used them to tie the vineyards. 
around four to five hours of footage do still circulate on Albanian media and the internet nowadays. Another part of the story is that 800 Kinostudio staff members were required to blanket Albania with recording groups during the national mourning days: each city (or two) was to receive one film director, one cameraman, and one editor. Field recordings were collected for the documentary film Dhimbje e thellë, betim i madh (A Deep Pain, a Great Oath) to the memory of the "Great Commander," which was hastily assembled in only five days. "All the cuttings — that is, miles of footage-were destroyed because we didn't have room to store them" recalls the film director Kujtim Gjonaj.?

The archives of the Institute for Folk Culture in Tirana (today the Institute for Cultural Anthropology) constitute a small but an important source of historical documentation: around 120 tape recordings of individual and collective laments, and around 300 lamentlike, commemorative, and glorifying songs for the leader, which were mostly copied by Radio Tirana, Radio Korça, and Radio Gjirokastra. Folklore researchers adopted a selective attitude toward local traditions, recording more lamentations in the south and fewer in northern Albania, probably because the leader came from the south. ${ }^{8}$ Ritual funeral lamentations improvised by women and men were recorded in the Lab region of southern Albania (May-October 1985). Though folk music was a powerful medium in which political language was installed and ideological messages were transmitted, the folklore researchers were mostly focused on the verbal content of the funeral crying. They recorded dozens of poetic texts from rural areas to distill the political-affective message of the people, while mostly ignoring the performative situation, emotional behavior, and musical expression of grief, pain, anguish, and denial of death.?

The funeral ceremony and national mourning for Enver Hoxha were systematically described in the daily newspapers Zëri i Popullit and Drita as well as in a special issue of the 1985 Albanische Hefte (Albanian Notebook), published by the Association of GermanAlbanian Friendship. The periodicals Kultura Popullore (1985) and Nëntori (1985) are saturated with pseudo-scientific and pseudo-artistic glorifications of Enver Hoxha as a great thinker. In addition, the Ministry of Education ordered all the pupils from six to eighteen years old to write a poem for Enver Hoxha, but only a small selection of this huge repertoire was published, in three volumes, as a sign of young people's unlimited devotion and self-sacrifice for the leader. One of the former political prisoners fortunate enough to survive the death of his persecutor, painter and architect Maks Velo, offers in his book Kohë antishenjë (A Time against the Sign) many keen observations and reflections of the event mixed with poetic imagination (2005: 214-234). Nowadays, the death of Enver Hoxha has

7 Conversation with film director Kujtim Gjonaj, Tirana, 2016.

8 Enver Hoxha was born in the southern town of Gjirokastra, and according to Albanian custom, every dead person is honored and mourned (more) in his/her birthplace, no matter where s/he is buried.

9 An anthology with glorifying and mourning folk songs created during the communist period for the death of Enver Hoxha was published by the Institute of Folk Culture under the title: Enver Hoxha tungjatjeta (Hail Enver Hoxha!; Kruta and Shituni 1986). 
become grist for the mill of media gossips, politically senseless debates, post-communist melodramas, and art exhibitions. ${ }^{10}$

Starting from these premises, the goal of this study is to discover something new or to rediscover what is already known about Enver Hoxha's death, state funeral, and public mourning. Taking into account the high political sensitivity of the topic, I avoided using a camera or audio recorder with informants in order not to influence our bisedë e lire (free conversation) — as one called it — and their individual memories and collective life stories. The historical sequence of mortem and post-mortem events is reconstructed within the narrative framework of diverse versions of reality. Even so, the qualitative methods, the narrative interviews, the group conversations (especially with former political prisoners and war veterans), the empirical-analytical inquiry of the data, and the superimposed interpretation from one's own experience cannot protect the researcher from stumbling from "uncertain truth into certain untruth" (Voegelin 1999: 310).

\section{DYING, DEATH, AND REACTION}

How can one "measure" the loss of a leader that was both adored as a folk deity of modernism and feared as a cynical killer protecting his absolute power? Do the limits of crying imply the limits of loss? The emotional trajectory of the dramatic situation comprises the disequilibrium of the political class, the self-absorbing involvement of common citizens, and the inward emigration of politically persecuted groups. Role taking and role performance can be grasped through the interpretation of the actor himself, who has internalized political guidelines and feels morally obliged to come into play and stay in play. ${ }^{11}$ Isuf Kalo, Enver Hoxha's personal doctor from 1973 until the end, offered me one of his favorite answers for the journalists: "I cured the dictator, but not the dictatorship." He considered Enver Hoxha a very "cooperative patient" with a "strong personality," who was never afraid of death. Dr. Kalo describes Hoxha's last moments on his deathbed surrounded by doctors and several members of his family and the politburo:

On April 9th, Enver collapsed senseless on the bed. He was hit several times in the chest and his heart rhythm was reset. His brain was not supplied with blood and he fell into a coma ... . His heart was still working but he was artificially kept alive. He passed away on April 11th .... Enver died happy and convinced that he had done the right things for his country. He saw all the jubilation and the euphoria of the crowd

10 The Albanian painter Ardian Isufi created an installation with Enver Hoxha's death mask called "AntiHomage to the Dictator," which was exhibited at the National Historical Museum in Tirana in 2015.

11 Today, one can easily observe that many Albanian citizens misremember their conformist behavior under the communist dictatorship. 
as a confirmation of his justice... . In a certain measure, we [the privileged people of the system] were all cheated, but Enver was the most cheated person. ${ }^{12}$

Enver Hoxha's widow was self-controlled ${ }^{13}$ and did not betray the slightest emotional reaction. She offered well-wishes to her husband's immediate successor: "May you have a long life, Comrade Ramiz!” (Të na rroni ju shoku Ramiz!). Hoxha's sisters, daughter, and daughter-in-law started to sob in an anxious, repressed way, each one "on her own" (e qarë $n \ddot{e}$ vete) without words, but no one was allowed to wail aloud at home. At five o'clock in the morning the lifeless body of the communist leader was carried by soldiers to the Tirana morgue. Muharrem Xhafa, the head of the propaganda department at the Central Committee in Tirana recalls that, on that dawn, Ramiz Alia called an extraordinary meeting with toplevel functionaries in Hall No. 80 of the Central Committee and ordered them to travel all over Albania and "to communicate the bad news orally, in order to keep the situation under control and avoid any tumult." ${ }^{14}$ The burial committee had been already established and logistical measures had been taken based on prior Soviet-style funerals for politburo members Gogo Nushi (1970) and Hysni Kapo (1979)..$^{15}$ The official announcement of the Central Committee of the Albanian Party of Labor was broadcast on TV and radio at 12:00 noon on April 11th, 1985. It was also published in a special issue of the newspaper Zëri $i$ Popullit on the same day and few days later in the weekly newspaper Drita.

Life, time, and normal activities were literally suspended and the whole population came together in big crowds to hear the breaking news. Virgjil Kule, the former director of Radio-Television and one of the most emblematic newsreaders in communist Albania, read the death announcement:

Comrades, communists, workers, cooperative-peasants, intellectuals, women, and young people of Albania, war veterans and compatriots. In deep sadness and pain we announce that today, on April 11th, 1985, at 2:15 am, the heart of our beloved and glorious Leader of the Party and the people, Comrade Enver Hoxha . . . ceased beating. (Announcement of Enver Hoxha's death 1985)

12 Conversation with Isuf Kalo, Enver Hoxha's personal doctor, in Tirana, 2016.

13 The widow's emotional reaction is described in different versions: to me, Teuta Hoxha re-confirmed that "she was very restrained," emphasizing her "strong character." But in her book she writes that Nexhmija "could barely stand . . . ; she didn't cry, murmured indistinct words to herself in a low voice, but the name Enver was uttered clearly" (Hoxha 2015: 199). Whereas Hoxha's escort, Sulo Gradeci adds in his book: "the crying with words (vajet e ligjet) of Comrade Nexhmije, his children, and his sisters were heard from the workroom" (Gradeci 1988: 414). Many informants affirmed to me that this "faithful servant" is not the actual author of the book on Enver Hoxha, thus pointing to the Institute for Marxist-Leninist Studies.

14 The word "tumult" (rrëmujë) seems to hint at the rebellions of political prisoners in Spaç (1973) and Qafë-Bar (1984) that were bloodily crushed by state authorities.

15 Enver Hoxha orchestrated the state funerals for his "brothers-in-arms" himself. 


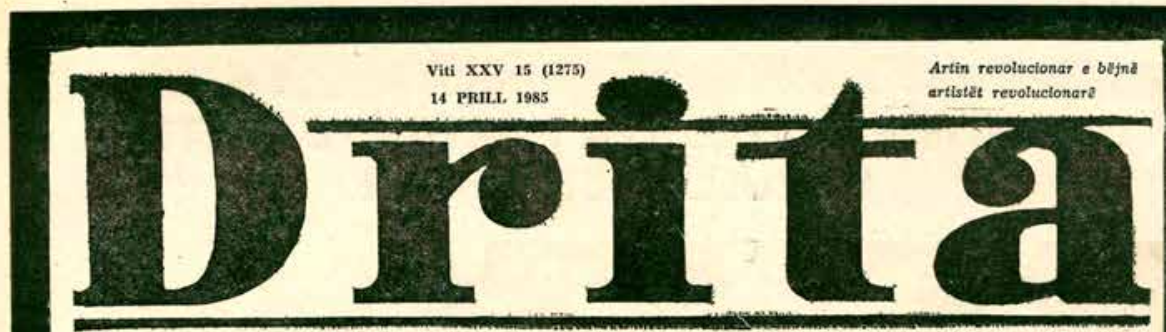

E PERJAVSHME LETRARE ARTISTIKE - ORGAN I LIDHJES SE SHKRIMTAREVE DHE ARTISTEVE TE SRQIPERISE

\section{DHIMBJE E THELLE PER PARTINE E GJITHE POPULLIN SHQIPTAR}

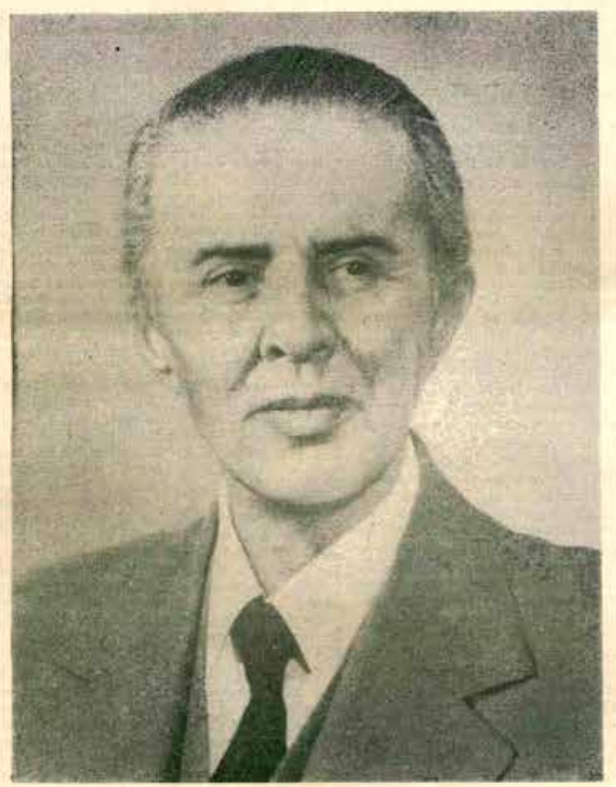

NJOFTIM I KOMITETIT QENDROR

TE PARTISE SE PUNES TE SHQIPERISE, PRESIDIUMIT TE KUVENDIT POPULLOR, KESHILLIT TE MINISTRAVE DHE KESHILLIT TE PERGJITHSHEM TE FRONTIT DEMOKRATIK TE SHQIPERISE

Shokê, komuniste, panžtore, kooperativiste, intelektuale, gra e te rinj te Shqipürisé, veterane te

Me hidhêrim e dhimbje ta thelle ju njoftojme se sot, me II prill 1985, ora 2.15 , pushoi sê rrahuri zo-

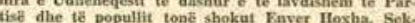
rotar 1 Parë i Komitetit Qendror tô Partise sहै Punïs

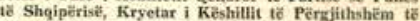
Frontit Demoliratik tê Shquiperrisé, Komandant Pèrgjithshëm i Foreave tê Armatosura tê RPS tê Shqipërisē.

U nda prej nesh themeluesi I Partisë sonö to tavdishme, organizatori dhe udbeheq Esi i Lafies Nacienalclinimtare e i revolucionit tone popullor, arki-

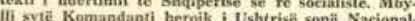
thrimitare, At qe kribot Frontin Demokratik the ho dhi themelet e Pushtetit Popullor.

Jeta dho Vepra o Enver Hoxhés, tashte historia

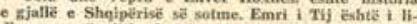
dhur me te gjitha betejat kasore dhe me tế gjitha fitoret e Partisé o te popullit shigipiar.

No te Ejatha etapat qe ka kaluar populti yné, qü nga dita kur u krijua Partia Komuniste e deri me tö At chent, laurdohere dimi the peronalteti i Tij, Na fo granstom men-

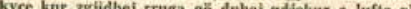
duhej zhvilluar, udhêtheqja dhe drejtimi i Tij kan qene vendimtare.

Revolucionar i bindur e patriot i devotshäm, Enver Hoxha ishte I pari ndër komunistët shqi-

\section{POPULLI YNE BEN HOMAZHE DHE NDERON ME RESPEKT DHE MIRENJOHJE TE THELLE SHOKUN ENVER HOXHA}

UDHEHEQESTT E PARTISE DHE TE SITETIT BEJNE ROJE NDER PRANE ARKIVOUT ME TRUPIN E UDHEIEQESTT TE DASHUR TE PARTSE E TE POPULTT, SHOKUT ENVER HOXHA.

Ka katêr dite qe Clamuri ora 7, mijêra njerezz nga le shïm te Frontit Demokratik tè

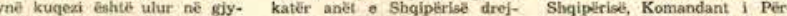

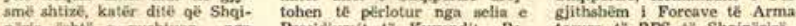
perria sishte e pushtuar nga Presidiumit te Kuvendit Po- tosura tê RPS tê Shqiperisê. dhimbja e madie Asnje se- pullor ku cahte vendonur arki- Vijne me radhe veteran mé nuk mesobet dot me lajmin e hiahur. Asikush nuk do te

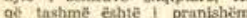
nể celo vatér tonkin, nuk feton mé Cida ditze ende pa shkua voli me trupin e shokut Enver Foxha, Uahienequestit to dashiur te populti la seltion Pare I Komiteit Qendror

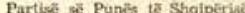
Kryctar i Keshillit to Persiath-

the ndogé hip pas hapi Komandantin me, ata ou lichil plaget dhe kénduan kénget partizane pra në zistreve to lufter me te Vijne vogëlushect, qut to

parin mésuan emrin -PartiErivers, vijne punétoret o veprave te savjegareve tanc, kooperativistet e fithatit sock ushtarake e krifues Vjen giithe Shqiptris

(1) Do arkivoli me trupin e sho kut Enver ut vendas né a salle

(vijon ne f. 7 )

Announcement of Hoxha’s death in the weekly newspaper Drita, April 14, 1985 
The emotions aroused by this "breaking news" varied extremely in intensity according to the social class hierarchy (peasants, workers, and intellectuals) and also one's affectivepolitical attachment to the system. B.F., a bookkeeper from Lumi i Vlorës in southern Albania, would never forget that "black day" when Enver Hoxha's death was communicated to the peasants of the area:

It was very hard to utter that HE had died, it was almost impossible. . I was in the village of Kote. People from the Central Committee had come precisely to declare the tragedy. We all gathered at the hall of the House of Culture. The politburo representative stood up with trembling hands. "Brothers and sisters... what we had never expected has already happened." Again silence. "Based on a decision of the Central Committee of Albanian Party of Labor as well as on behalf of Comrade Ramiz Alia, I must communicate you that the supreme commander of Albania, Enver Hoxha, has closed his eyes" [here my informant's voice became very plaintive]. The people in the hall stood up and burst into shouting and howling. Even now I have emotions. I was there. I spent about fifteen days without eating [only water, coffee, and cigarettes ${ }^{16}$ ]. God in the heavens knows that I am telling the truth. And not only me, but also my old mother and my wife. That was our time, and man cries his own time. ${ }^{17}$

The death of Enver Hoxha was suffered as a "devastating catastrophe," bewailed as "disappearing of the sun," and denounced as a "scientific failure" (see Kultura Popullore 1985: 165-199; Zëri i popullit, April 11th-30th, 1985; Drita April 21st-May 12th, 1985). Various experiences of being deeply shaken were enacted all over rural Albania, and these were also confirmed by politically persecuted people. The historian Uran Butka, who had been interned by the communist regime in the Martanesh area of northern Albania (19751988), brings onstage a plurality of dramatis personae with conflicting emotional reactions:

I was in Martanesh. We heard the news about Enver's death on the radio. It was an incredible joy, I embraced my wife, we forgot our troubles, we forgot that we were in Martanesh. We felt hope and joy. [Persecuted] people expected the death of Enver to be a salvation. After that, on April 11th all the residents were called to join at the central square in the village of Peshk. A loudspeaker and a portrait of Enver Hoxha were put in front of the House of Culture. About 300-400 persons from four to five nearby villages were present. A State Security officer was ordered to watch the reactions of the politically persecuted people. One could read satisfaction in the faces of the reactionaries and the banished and dispossessed wealthy farmers (kulak) [but

16 When Lab men were "poisoned" by bitter sadness and painful anger, they did not smoke their cigarettes but ate them up.

17 Conversation with B.F., a bookkeeper from the village of Kotë; Vlorë, 2016. 
they had to hide it]. The privileged people of the communist system: the head of the cooperative, the administration staff, the teachers, and the community were at the peak of despair. Men and women cried in horror. All the pupils of the elementary school, even the children of the politically persecuted people, cried with them, because they all were indoctrinated. A lamenting-woman from the village-quarter of Kasollexhinj started "to cry with words" (e qarë me ligje), ${ }^{18 ~ " w i t h ~ a ~ w a i l " ~(m e ~ o i) ~ f o r ~ a b o u t ~ 3-4 ~}$ minutes. She recounted the values of the leader. The wife of a communist tore her hair out and shouted. Another woman fainted, while foaming at the mouth in a kind of epileptic seizure. One could notice a fakery, a "making as if" among some intellectuals and kulaks, and it was precisely here that the situation became tragicomic. ${ }^{19}$

Class roles and reference groups, projected onto a plane of simultaneity, became ritually and symbolically present. The extraordinary funeral situation was penetrated by latent functions that were fulfilled without being expressed, by the exercised power of instrumental control and the spiritual assets of the communist regime. The xenophobic fear, the paranoid state of siege, and the warlike attitude toward predatory neighbors and internal enemies that characterized Hoxha's ideology and regime were temporarily increased after his death: if a foreign enemy attacks Albania, we will kill you first! said an officer to political prisoners. ${ }^{20}$ Despite this, the political prisoners in Burrel, in northern Albania, refused to sign the letter of condolences for the widow Nexhmije Hoxha demanded by the prison authorities, and their dangerous resistance signaled the triumph of the survivors and their celebrated togetherness.

\section{PAYING HOMAGE TO THE LEADER}

Meanwhile, the Central Committee of Albanian Party of Labor decided to announce eight National Mourning Days (from April 11th to 18th) in order to honor the memory and deeds of the beloved leader of the party and the people:

All theater performances, cinemas, concerts, and other entertainment and sports activities must be cancelled. ${ }^{21}$ During the burial ceremony, work must be interrupted in all institutions and production centers and the sirens of factories, trains,

18 The technical terms e qarë me ligje and me oi are used only in the south but not in northern Albania. The local terms for northern funeral crying are me kja (to cry), me njeh (to recount), me kukat (to coo).

19 Conversation with historian Uran Butka, who was interned in Martanesh, northern Albania; Tirana, 2016.

20 Conversation with former political prisoner Uran Kostreci, held in Burrel, Peqin and Sarandë; Tirana, 2016.

21 During the mourning days even alcoholic drinks were prohibited, and this measure was based on Albanian traditional practices: when men participate in a funeral ceremony, they put the glass to their lips without drinking the alcohol; this customary gesture symbolizes the sad event. 
and ships must sound for five minutes. At the same time, a twenty-one-gun salute must be fired at the capital city of our Fatherland, Tirana, and a five-gun salute in the cities of Gjirokastër, Vlorë, Krujë, Korçë, Peshkopi, Shkodër, Kukës, Berat, Durrës, and Elbasan. (Zëri i Popullit, April 11, 1985, p. 2)

The official obsequies for the leader took place at the Presidium of the People's Assembly (Presidiumi i Kuvendit Popullor). Three RTSH make-up artists went to the Tirana morgue to prepare the corpse for public display, but one of them was terribly shocked and fainted on the spot. Enver Hoxha had undergone plastic surgery, and the skin of the face was stretched, tightened, and gathered on the back side of his head: I gave him a light pink nuance to make him look alive, she told me in a reluctant voice. ${ }^{22}$ The military structures for the funeral procession were arranged by Rustem Peçi, the commander of the united military school in Tirana. As soon as the lifeless body was prepared for the ritual mise-enscène, the widow Nexhmije Hoxha said to family members: Control yourselves! I don't want to hear you crying in front of the people! Maintain your dignity!

The shocking situation called for broad public participation in order to reaffirm the national unity, increase the significance of party leadership, and regenerate the inner binding force between them. Five representative members from each of the political, military, and academic institutions, factories, and cooperatives throughout Albania were designated to participate at the funeral ceremony. Two halls of the presidium were opened: one for public viewing of the dead body and one for receiving the politburo, diplomatic corps, personalities, Heroes of Socialist Labor, and mothers of dead heroes. The homages started at nine in the morning and ended at eight in the evening; they were periodically interrupted two to three times per day, to enable the bereaved family to be alone in the hall with their deceased. These breaks lasted only ten to fifteen minutes, because the line of the people waiting outside was three to four kilometers long. When Nexhmije stayed next to the coffin of her husband, she lamented with words (vaj me fjalë) but not aloud, reports Teuta, the older daughter-in-law. And she further recalls that the southern Albanian women's crying with words were very short but emotionally powerful: people showed a truly felt pain and there was no falsity in that. During the funeral ceremony at the presidium, we had to console the people crying for Enver Hoxha. ${ }^{23}$

The grandiose public mourning in capital city of Tirana turned the state funeral into a musical drama within the political drama. The noisy, emotionally uncontrollable state of collective "perturbation" (trazim) is culturally resolved through women's "crying out of order," or free integrative crying. ${ }^{24}$ But the circularity of official images between the

22 Conversation with E.L., a make-up artist at Albanian Radio-Television (RTSH); Tirana, 2016.

23 Conversation with Teuta Hoxha, the daughter-in-law of Enver Hoxha; Tirana, 2016.

24 Within the Albanian cultural domain of death and mourning, free crying signifies the most dramatic situations of a funeral ceremony, where bereaved kinswomen sob, wail, and speak to the dead simultaneously but each on her own. This practice, locally known as tuj kja ni hierit (crying at the same 
imposed duty of public mourning and its affective object, or the ideological discourse and its eventful referent, are only the tip of the iceberg. ${ }^{25}$ The former director of RTSH observed that "many people at the ceremony cried and wailed only to attract the attention of the higher authorities"; especially striking one's head with one's fists was very theatrical and ridiculous in the observers' eyes. Conversely, a former political prisoner projected his own feelings and imagination on the mourning crowd paying homage to the leader:

\section{I was in prison and saw the events on TV. It was a theater. I guess the majority of the people were happy that he died . . but they couldn't laugh openly. . . [t]hat's my impression. The crying of some brainwashed bitches, stupid women, and hypocrites does not represent the majority of Albanian society. . . . The people who were deeply saddened and really cried hard had committed crimes during the communist period. ${ }^{26}$}

Despite these entirely opposite interpretations of the same event, many participants unanimously affirmed to me that the orphans of the Shtëpija e Fëmijës (House of Children) were shaken to the bottom of their hearts and cried more than anyone else. Unlike women, Albanian men assume that "not crying is an act of bravery" and this customary attitude was politically integrated into the motto: "turn pain into strength!" (ta kthejmë dhimbjen $n \ddot{e}$ forcë!).

\section{THE MUSICAL AND POETIC LANDSCAPE}

Dictatorial regimes have the most self-evident manifestations of music as an attribute of power, social control, and cultural repression. Culturally patterned sounds facilitate the consumption of nationalist mythology more suggestively than images and thus establish an interactive medium of communication free from the bi-referentiality of language. The adequate employment of ethnographical concepts enhances the understanding of musical events and their specific situations in which they are created, performed, felt, and perceived. The musical landscape of "pain until shock for Enver Hoxha" was shaped by a constellation of diverse sonic events:

time) in the north or e qarë pa rend (crying out of order) in Myzeqe, southern Albania has a liberating and integrative function on an emotional, moral, psychological, and social level. Free integrative crying undermines the formal order of a disciplined performance and regenerates a collective unity in loss and pain (Kondi 2012: 127-131).

25 I was seven-year-old child when Enver Hoxha died, and the conflicting attitudes of my parents have been carved into my memory: the tearful anguish of my mother, a worker, and the indifferent quietude of my father, a high officer.

26 Conversation with former political prisoner Uran Kostreci, held in Burrel, Peqin and Sarandë; Tirana, 2016. 
(a) Natural sobbing, verbalized crying, funeral singing;

(b) Folk instrumental crying;

(c) European classical music transmitted on the radio and TV;

(d) Funeral marches composed ad hoc by two Albanian film composers;

(e) The howling sirens.

The Albanian term qaj has four complementary meanings: (a) "to sob," "to shed tears"; (b) "to cry," "to lament" with or without words; (c) "to complain"; and (d) "to do something perfectly" (Kondi 2012: 314). Within the framework of customary mourning (zija) as an affective state, color of bereavement, and lamenting act, it must be clarified that natural mass sobbing (dënesa) for Enver Hoxha was documented nationwide, whereas ritual "crying with words" was basically a local event, observed more in southern and less in northern regions. Many ritual collective and individual funeral crying episodes for Enver Hoxha were generally adopted from the oral funeral traditions of the village and were performed in front of his portrait. A significant case comes from Lumi i Vlorës: a bereaved woman praised her dead brother-in-law in a very short, condensed, expressive crying, typical of the Lab region in southern Albania: ${ }^{27}$

Viti nëntëqind e tetë u kthye lumi përpjetë, se lindi Hamzua me fletë.
In the year 1908, the river flowed upwards, because Hamza, a brave man with wings, ${ }^{28}$ was born.

These poetic verses in a haiku style affirm that, whenever a great man dies, the natural order of things changes. A folk poet from the same area appropriated this female crying that was fixed in social memory and attributed it to the dead Father of the Nation. But all the texts collected in the field were published by folklore researchers without crediting the sources. Feti Brahimaj, a well-known folk poet from Lapardha, southern Albania, wrote two long poetic texts when he heard the death news and when he was watching the burial scene on TV. Both multipart songs were recorded by a Lapardha folk group at Radio Tirana on April 28th, 1985. I will tell you some verses for the darkest day, Feti told me: ${ }^{29}$

Ditët e prillit u nxinë, s'bënë as bar as trëndelinë, ç'janë ato shirita zije, që po i bëjn malit hije? Ndaluni shokë, ku po shkoni,
The April days were blackened,

Neither grass nor flowers would sprout, What are those mourning bands [the dark clouds] Casting their shadow on the mountain? Stop, my friends, where are you going,

27 Conversation with Bardhosh Gaçe, folklore researcher at the University of Vlora; Tirana, 2016.

28 The "brave man with wings" symbolizes the dragon in the Albanian folk imagination.

29 Conversation with Feti Brahimaj, a folk poet and singer with the folk vocal group of Lapardha; Vlorë, 2016. 
flasin zëmrat a dëgjoni?

Enver Hoxhën ku e çoni?

Aman në vorr mos pranoni!

Ktheheni se e pret timoni,

e pret zyra ku punoi,

tribuna ku ligjëroi,

në kongres e pret salla,

e pret nënë faqebardha,

e pret shamikuqja motër,

Tiranë, Gjirokastër, Shkodër...

për ty bie cula dyjare,

për ty këndon çiftelia,

të do isua dhe oi-ja,

sa shumë të do historia.
The hearts are calling, do you hear them?

Where are you carrying Enver Hoxha?

Please, don't accept putting him in the grave!

Bring him back, the steering wheel is waiting for him,

His work office is waiting for him,

The podium where he delivered his speeches,

The crowd is waiting him for the congress,

The white-honored mother is waiting for him,

The sister with red scarf $\mathrm{f}^{30}$ is waiting for him, In Tirana, Gjirokastër, Shkodër . . .

The double reed is playing for you,

The lute is singing for you,

The drone and the wailing are imploring you,

Oh, how much does history need you.

The melodic type and crying style are based on a "song of pain for a killed hero" (këngë derti për një trim të vrarë) which represents the powerful softness of multipart songs in Lab area. But the strictly prescribed order of mourning events left nothing to chance. One of the members of the famous traditional ensemble Sazet e Përmetit in southern Albania recalled that on April 11, the local authorities woke up the musicians at midnight and sent them immediately to Radio Tirana to play kaba labiko (instrumental crying in the Lab style) for the death of the Leader. ${ }^{31}$ Unlike Albanian traditional music, which filled certain hours of the daily program, the funeral march from Beethoven's Third Symphony was heard constantly in the hall and on radio and TV. It served to color the dramatic situation, to hide the anguish behind a sonic curtain, and to keep the situation under control. During the mourning days, the high authorities ordered the film composers Limos Dizdari and Kujtim Laro to each compose a "national funeral march" for Enver Hoxha within fortyeight hours. This request was simply based on the ideological principle that "we must rely on our own forces!" (të mbështetemi në forcat tona!).

The composers were individually sequestered at different institutions and guarded by soldiers, because making music at that moment would have been misunderstood as entertainment, and that would have been politically dangerous and brought harsh consequences. Both marches were composed within one night, immediately orchestrated by the chief conductor of the military band, and performed on the burial day, April 18th. Unfortunately, the score and recording of Dizdari's funeral march are lost. The composer recalled that his Romantic-style funeral march had a three-part structure: mourning (A) - hailing (B) - mourning (A), which aimed to express the emotional and political attitude of the people: we are really crying for you, but we will celebrate only your birthday. ${ }^{32}$ Indeed,

30 The "red scarf" is a symbol with multiple meanings: it refers to the bride in Albanian tradition as well as the Albanian national flag, but also to the color of communism.

31 Conversation with Fredi Daci, member of the Albanian traditional Ensemble Sazet e Përmetit; Bonn, 2019.

32 Conversation with composer Limos Dizdari; Tirana, 2016. 
even the date of Hoxha's death was not inscribed on his tombstone and his death date was never commemorated in communist Albania.

Because the Bolsheviks had abolished church authority, the deaths of Lenin and Stalin were not announced by tolling of the bells but by factory sirens ${ }^{33}$ and train whistles (Tumarkin 1983: 162). Tito's death was commemorated every year in Yugoslavia by observing one minute of silence associated with wailing sirens (Bringa 2004: 169). The five-minute silence observed for Enver Hoxha during his burial ceremony was filled with multiple sirens, which symbolized the alarm of an anxious Albania and the howl of the imaginary bereaved world proletariat.

\section{WORSHIP, SECOND BURIAL, AND POLITICAL AFTERLIFE}

The unique memory of the name, power, and myth of Enver Hoxha called immediately for glorious representations of his public presence and permanent radiance. On April 13th, 1985, the eleventh plenum of the Central Committee of the Albanian Party of Labour (PPSH) adopted a decision for the "immortalization of the name and deeds of Comrade Enver Hoxha": statues of the leader were raised in Gjirokastër (his birth town), Korça (where he had worked as a teacher), and Tirana (where he entered as a WWII victor and lived and worked until his death). The state university of Tirana, the port of Durrës, an agricultural enterprise in Korça region, and the Organization of Pioneers were all named after him. The Day of Enver was proclaimed and all the children and students celebrated it with songs, dances, and making red stars all over Albania (Zëri i Popullit April 11th-18th, 1985). ${ }^{34}$

The leader's grave, in the shadow of the "Mother Albania" monument, became a locus of worship rituals and solemn oaths on the Day of Heroes (Dita e Dëshmorëve). A new "altar" was raised in every Albanian family: a small white bust of the Great Leader against the dark-red background of 70 volumes written by him. This religious form of reverence for the leader is undoubtedly derived from Lenin's icon corner of Russian peasant homes. In May 1985, the politburo issued a directive intended for all film directors to produce documentaries covering Enver Hoxha's visits to the twenty-six regions of communist Albania. Only half of them were finalized and production of the new series Enver Hoxha dhe rrethet (Enver Hoxha and the Regions) was interrupted a year later due to the progressively worsening economic situation. ${ }^{35}$ The National Folk Festival of Gjirokastra (1988), which was

33 The rising and falling sound of air-raid sirens also served to announce Hitler's speeches on German radio during WWII.

34 Elidor Mëhilli reports that Enver Hoxha "had occasionally objected in PPSh Politburo meetings to all kinds of excesses: plans to name factories and schools after him; party officials' eagerness to convert his childhood home into a communist shrine; and the engrained habit of showering him with gifts at birthdays and anniversaries" (Mëhilli 2011: 4).

35 Conversation with film director Kujtim Gjonaj; Tirana, 2016. 
held every five years in the leader's birth town, brought 353 songs, dances, instrumental pieces, and ritual scenes to the stage. Twenty-eight commemorative songs were created for Enver Hoxha (ca. 8\% of the whole festival) and the message they transmitted can be summed up in two complementary key phrases from northern and southern Albania: "A song is too small for such a great man" (nuk ka kangë që e nxe at burr') but "when he enters a song, he remains there forever" (byn në këngë e nuk del kurrë). When Mother Teresa was finally allowed to visit communist Albania in 1989 and found her Mission of Charity, the political leadership asked her to pay homage to Enver Hoxha at the cemetery of National Heroes. The media images showing the "Great Mother" placing flowers at the grave of a dictator that had uprooted religion and executed the clergy aroused many contentious debates in post-communist Albania.

Enver Hoxha's peaceful passing in 1985 contrasts strongly with the violent rituals of state disintegration in post-communist Albania (1991-1992, 1996-1998). ${ }^{36}$ His repressive cult was convulsively rejected in a Oedipal patricide: his statue in the central square of capital city was overthrown in the style of a public execution and his remains were exhumed from the Hill of National Heroes and disposed of at the civil cemetery of the capital city. But all these acts do not complete the mythical twilight of gods, their damnatio memoriae, because the old traces are rediscovered in a series of new beginnings. The Albanian dictator was still "present in absence," and his death directly affected the old structures of authority without changing the substance of his regime. ${ }^{37}$ On significant dates in the Albanian political calendar, his grave was either violated and defiled or repaired and flower-bedecked (Hoxha 2015: 259-264).

The figure of Enver Hoxha is gradually being reanimated and rehabilitated by members of the Communist Party, war veterans, and nostalgic groups in Albania and Kosovo. They gather at Hoxha's graveside and openly celebrate his "unforgettable deeds and memory" while holding speeches and singing multipart songs for the (re)construction of socialism because Albanian socialism was the right line but its application went wrong. ${ }^{38}$ In many weddings in Kosovo, it is customary to sing the glorifying song "Hail Enver Hoxha" (Enver Hoxha tungjatjeta) as well as a commemorative song for Adem Jashari, a symbol of resistance against the Serbian genocide. But the ambiguous relationship with Enver Hoxha seems to reflect more affinity for stern, fair leadership as a bulwark against corrupt post-communist politics rather a respect for the dictator himself. Many former political prisoners feel assaulted by

36 Despite the societal modernization of a belated nation, the implosion of the communist dictatorship in 1991 revealed a politically naive populace that was unable to form a democratic state.

37 Conflicting attitudes towards Enver Hoxha share similar traits with the ambivalent cult of Tito in the Yugoslav successor states, in which he is both glorified as a hero and denigrated as a traitor (Stevanović 2016: 106-112). Concerning the discrepancies and ambiguities of hero cults in post-communist Central Eastern Europe see also Povedák 2014 and Fikfak 2014.

38 Conversation with Etem Halili, former officer and member of the National Committee of the NationalAntifascist War Veterans; Tirana, 2016. 
the communist nostalgia spreading among the public, but they still are strong enough to come to terms with their past and present. As one of them states:

Let me tell you something with my whole heart. Forget my personal sufferings in prison, forget what communism did to me . . . Thank God I am alive . . . Enver Hoxha not only killed or imprisoned his people, stole their property, and isolated them from the world for fifty years, but he deformed the mind and character of Albanians. For that, I will never forgive communism. ${ }^{39}$

\section{REFERENCES}

Announcement of Enver Hoxha’s death. 1985. Breaking News April 11, 12:00 pm, Albanian RadioTelevision, Tirana.

Arendt, Hannah. 1962 (1952). The Origins of Totalitarianism. Cleveland and New York: Meridian Books.

Bartl, Peter 1995. Albanien. Munich: Friedrich Pustet Regensburg.

Borneman, John (ed.). 2004. Death of the Father: An Anthropology of the End in Political Authority. New York: Berghahn Books.

Bringa, Tone. 2004. The Peaceful Death of Tito and the Violent End of Yugoslavia. In: John Borneman (ed.), Death of the Father - An Anthropology of the End in Political Authority. New York: Berghahn Books, 148-200.

Di Nola, Alfonso. 2003. La Nera Signora - Anthropologia della morte e dell lutto. Rome: Newton \& Compton Editori.

Drita. 1985. Weekly literary newspaper, April 11-May 12. Tirana: Lidhja e Shkrimtarëve dhe Artistëve.

Durkheim, Emile. 2001 (1912). The Elementary Forms of Religious Life. New York: Oxford University Press.

Fikfak, Jurij. 2014. Leaders and Heroes of the Nation. Traditiones 43 (1): 7-11. DOI: https://doi.org/10.3986/ Traditio2014430101.

Fischer, Bernd. 2007. Enver Hoxha and the Stalinist dictatorship in Albania. In: Fischer Bernd J. (ed.), Balkan Strongmen: Dictators and Authoritarian Rulers of South-Eastern Europe. West Lafayette, Indiana: Purdue University Press, 239-268.

Freud, Sigmund. 2001 (1920-1922). The Standard Edition of the Complete Psychological Works of Sigmund Freud: 'Beyond the Pleasure Principle,' 'Group Psychology,' and Other Works. Vol. XVIII. London: Vintage.

Gradeci, Sulo. 1988. 30 vjet pranëshokut Enver. Tirana: Shtypshkronja e Re.

Großbölting, Thomas, and Rüdiger Schmidt (eds.). 2011. Der Tod des Diktators - Ereignis und Erinnerung im 20 Jahrhundert. Munich: Vandenhoeck \& Ruprecht.

Halliday, Jon (ed.). 1986. The Artful Albanian - The Memories of Enver Hoxha. London: Chatto \& Windus. Hoxha, Teuta. 2015. Enveri në kujtimet e mia. Tirana: Ilar.

39 Conversation with former political prisoner Uran Kostreci, held in Burrel, Peqin and Sarandë; Tirana, 2016. 
Koenen, Gerd. 1992. Die grossen Gesänge. Lenin, Stalin, Mao Tse-tung: Führerkulte und Heldenmythen des 20. Jahrhunderts. Frankfurt am Main: Eichborn Verlag.

Kondi, Bledar. 2012. Death and Ritual Crying - An Anthropological Approach to Albanian Funeral Customs. Berlin: Logos.

Kruta, Benianim, and Spiro Shituni. 1986. Enver Hoxha Tungjatjeta. Tirana: Shtypshkronja e Re.

Kultura Popullore. 1985. No. 1. Tirana: Akademia e Shkencave të Shqipërisë.

Lendvai, Paul. 1985. Traveller in Albania - Letter from Tirana. Encounter 65 (3), September-October: 62-74.

Mëhilli, Elidor. 2011. Defying De-Stalinization. Albania’s 1956. Journal of Cold War Studies 13 (4): 4-56. DOI: https://doi.org/10.1162/JCWS_a_00169.

Min, Choi Song. 2012. Harsh Punishments for Poor Mourning. Daily NK, November 1. http://www. dailynk.com/english/read.php?num=8668\&cataId=nk01500.

Povedák, István 2014. 'Survivor Heroes’ and Rising Heroes: Discrepancies in the Contemporary Hero Cult. Traditiones 43 (1): 66-77. DOI: https://doi.org/10.3986/Traditio2014430106.

Rader, Olaf. 2003. Grab und Herrschaft, Politischer Totenkult von Alexander dem Großen bis Lenin. München: C. H. Beck.

Schoeberlein, John S. 2003. Doubtful Dead Fathers and Musical Corpses: What to Do with the Dead Stalin, Lenin, and Tsar Nicholas? In: John Borneman (ed.), Death of the Father - An Anthropology of the End in Political Authority. New York: Berghahn Books, 201-219.

Stevanović, Lada. 2016. Josip Broz Tito: Hero of the Nation or Traitor? Traditiones 45 (1): 105-116. DOI: https://doi.org/10.3986/Traditio2016450107.

Tumarkin, Nina. 1983. Lenin Lives! The Lenin Cult in Soviet Russia. Cambridge: Harvard University Press.

Verdery, Catherine. 1997. The Political Lives of Dead Bodies. New York: Columbia University Press.

Voegelin, Eric. 1999. Modernity Without Restraint: The Political Religions, The New Science of Politics, and Science, Politics, and Gnosticism. Columbia: University of Missouri Press.

Zëri i Popullit. 1985. Daily newspaper, April 11-30. Tirana.

Zëri i Popullit. 1985. Dhimbje e thellë, për Partinë e gjithë popullin shqiptar. Vdiq udhëheqësi ynë i dashur, shoku Enver Hoxha. April 11, special edition. Tirana. 


\section{TUDI BOGOVI UMIRAJO...: \\ DRŽAVNI POGREB IN NACIONALNO ŽALOVANJE ZA ALBANSKIM KOMUNISTIČNIM DIKTATORJEM ENVERJEM HOXHO}

Avtor obravnava državni pogreb in nacionalno žalovanje za diktatorjem Enverjem Hoxho (1908-1985). Za propagando komunistične diktature v Albaniji (1945-1991) je bila nesmrtnost voditelja pomemben simbol nacionalne nesmrtnosti. Zato je smrt oboževanega vladarja doživela kot nevzdržen škandal, ga objokovala kot "konec sveta in hkrati obsojala kot "znanstveni neuspeh«. Pogrebne komemoracije, javno žalovanje za »Vlikim ljubljenim vodjem«, spominski obredi in glasbeni spektakli ter "faraonska ovekovečenja "Enverja Hoxhe v piramidalnem muzeju nam dajejo predstavo o diktatorskem sistemu v najbolj izolirani državi v Evropi.

Ritualno dramo ob diktatorjevi smrti avtor razlaga $z$ analizo neposrednih izkušenj treh ciljnih skupin družbene hierarhije, tj. politbiroja, navadnih ljudi in razrednih sovražnikov, ki ponazarjajo ljubezen do vodje ali sovraštvo do diktatorja. Na žalost je iz arhiva albanske radiotelevizije izginila avdiovizualna dokumentacija celotnega državnega pogreba; zato je mogoče zgodovinsko zaporedje dogodkov rekonstruirati le v pripovednem okviru različic resničnosti.

Ob tem je paradoks razlage v tem, da več ko je na voljo informacij o zločinskih "nesrečah « in nasilju komunizma nad prebivalstvom in nacionalnimi kulturami, manj je, tako se zdi, mogoče razumeti slavnostno orgijo malikovanja in množičnega žalovanja za preteklim diktatorjem. Žalne slovesnosti so bile po zgledu Lenina organizirane za komunistične diktatorje, npr. Stalina, Mao Zedonga, Kim il Sunga, Enverja Hoxho, pospremljene z množično histerijo, obrednim gledališčem joka in čaščnjem prednikov. Diktatorski režimi uporabijo najbolj samoumevne manifestacije glasbe, da z njimi izrazijo moč ter izvajajo družbeni nadzor in kulturno represijo. Raziskovanje glasbene znotraj politične drame tako omogoča razumeti, kako smrt vodje razbija ideološko zamrznjene oblike zavesti in sinhroniziran ritem komunističnega življenja.

Dr. Bledar Kondi

Martin-Luther-University, Institute for Music, Media Studies and Linguistics

Kleine Marktstrasse 7, D - 06108 Halle, Germany,

bledar.kondi@musikwiss.uni-halle.de 